\title{
EFFECTS OF ROSMARINUS OFFICINALIS AND/OR OCIMUM BASILICUM SUPPLEMENTATION ON INDUCED DIABETES IN ADULT MALE ALBINO RATS
}

\author{
By \\ Saied Sharaf Mohamed \\ Medical Physiology Department, Faculty of Medicine, Al-Azhar University, Cairo \\ E-mail: saidmontaser859@gmail.com
}

\begin{abstract}
Background: Diabetes mellitus (DM) is a metabolic syndrome that is rising in prevalence worldwide in both humans and animals. It is characterized by persistent hyperglycemia and is caused either by inadequate insulin secretion from pancreatic beta cells, impaired insulin signaling, or both.
\end{abstract}

Objective: To evaluate the possible protective effects of rosmarinus officinalis and/or ocimum Basilicum on induced diabetes in adult male albino rats.

Material and methods: The present work was carried out form 15th of June to 30th of July 2021. Fifty adult male albino rats of local strain weighing $135-150 \mathrm{~g}$ were chosen to be the model of the present study and kept in suitable cages ( $45 \times 30 \times 30 \mathrm{~cm}, 5$ rats per cage). They were divided into five equal groups: Group I (Control group) received no treatment; Group II (Diabetic group) was subjected to induction of diabetes by intraperitoneal alloxan injection (120mg/kg BW for two days), Group III (Rosemary group) subjected to induction of diabetes and received Rosemary fortified diet (at 0.05\%) for four weeks, Group IV (Basil group) subjected to induction of diabetes and received Basil fortified diet (at 0.05\%) for four weeks, and Group V (combined group) subjected to induction of diabetes and received Rosemary and Basil fortified $(0.025 \%$ each) diet for four weeks. Checking of blood glucose was done, rats with high blood glucose $(250 \mathrm{mg} / \mathrm{dl}$ or more) were considered diabetic. At the end of the study, blood samples were withdrawn and serum was separated for determination of serum fasting glucose, insulin, glutathione (GSH), catalase (CAT), superoxide dismutase (SOD), lactate dehydrogenase (LDH) and malondialdehyde (MDA).

Results: Rats of groups III, IV and V showed significant decreases in serum glucose levels in comparison to the control group. In addition, dietary fortification with Rosemary and/or Basil significantly increased glutathione, superoxide dismutase, and catalase levels, while values for malondialdehyde and lactate dehydrogenase were decreased.

Conclusion: Dietary fortification with Rosemary and/or Basil leaves powder at $0.05 \%$ separately or $0.025 \%$ in combination might be used as promising modulators of blood glucose levels as well as nutritional management tools for the prevention and control of diabetes mellitus.

Keywords: Basil, Rosemary, diabetes, hypoglycemia, insulin, antioxidants.

\section{INTRODUCTION}

Diabetes mellitus is a common metabolic syndrome characterized by hyperglycemia resulting from decreased insulin secretion, insulin resistance or both. It is associated with common symptoms as polyuria, polydipsia and weight loss, in addition to long term complications which could cause organ damage, dysfunction and failure (Asano et al., 2014). 


\section{SAIED SHARAF MOHAMED}

Despite significant advances in management of diabetes, it stills a public health problem. Changing lifestyle and diet habits cause increased prevalence of diabetes all over the world (Hassanpour et al., 2017).

Clinical evidence suggests that diabetes is associated with oxidative stress leading to increased production of reactive oxygen species (ROS) as a result of disturbed oxidant/antioxidant system (Ranasinghe et al., 2017).

Diets play an important role in diabetes regarding prevalence, disease severity and management of the disease. Medicinal herbs have been used to prevent and/or control metabolic, nutritional and healthrelated diseases in both humans and animals focusing on dietary components that are beneficial in the prevention and/or modulation of the disease progress (Hosni et al., 2017).

Rosemary and Basil possess antihyperglycemic effects so, they could be used as promising natural remedies that can prevent and control DM in humans and animals. Rosemary contains many biologically active compounds, including volatile fractions and a variety of phenolic compounds that exert multiple biological activities, including hypoglycemic, antioxidant, cholagogue, choleretic, antidiuretic, anti-inflammatory, hypolipidemic, and hepatotonic properties (Labban et. al. 2014).

Al-Nahdi (2012) evaluated the influence of Rosemary extract (RE) on streptozotocin-induced diabetes in rats and reported that Rosemary significantly decreased blood glucose levels by $36.9 \%$.
Basil (Ocimum Basilicum) has long been used in traditional herbal medicine for the management of diabetes. It has been reported that diabetic rats supplemented with Basil extract for 2 weeks showed a significant reduction in both fasting and postprandial blood glucose levels (Ezeani et al., 2017).

Suanarunsawat et al. (2014) was conducts a study to evaluate the influence of Basil extract on blood glucose level in diabetic rats for 3 weeks and reported that Basil extract significantly reduced blood glucose level which was explained by possible positive effects on pancreatic $\beta$ cells function which was supported by increased insulin level in diabetic rats treated with Basil extract.

The present study was carried out to explore the possible protective effects of Rosmarinus officinalis and/or Ocimum Basilicum on induced diabetes in adult male albino rats.

\section{MATERIALS AND METHODS}

The experimental protocol and animal handling were approved and performed according to the guidelines of animal use of the Ethical committee of Faculty of Medicine- Al-Azhar University. Fifty adult male albino rats of local strain weighing 135 - $150 \mathrm{~g}$ were chosen to be the model of the present study. They were left for two weeks in the laboratory room before any experimental interference for acclimation with free access to water and rat chow pellets. Rats were kept in suitable cages $(45 \times 30 \times 30$ per 5 rats) at room temperature with the natural light/dark cycle. Rats were divided into five equal groups: 
Group I (Control group): received no treatment and served as a control group.

Group II (Diabetic group): was subjected to induction of diabetes by intraperitoneal alloxan injection (120 $\mathrm{mg} / \mathrm{kg}$ BW for two days). Checking of blood glucose was done. Rats with high blood glucose $(250 \mathrm{mg} / \mathrm{dl}$ or more) were considered diabetic.

Group III (Rosemary group): was subjected to induction of diabetes as group II and received Rosemary fortified (at $0.05 \%$ ) basal diet for four weeks.

Group IV (Basil group): was subjected to induction of diabetes as group II received Basil fortified (at $0.05 \%$ ) basal diet for four weeks.

Group V (combined group): was subjected to induction of diabetes as group II received Rosemary and Basil fortified $(0.025 \%$ each $)$ diet for four weeks.

Induction of diabetes: Diabetes was experimentally induced by intraperitoneal alloxan injection $(120 \mathrm{mg} / \mathrm{kg} \mathrm{BW})$ for consecutive two days. To avoid alloxan induced fatal hypoglycemia, treated rats were allowed to drink 5\% glucose solution instead of water over 24 hours following each injection. Five days later, checking of blood glucose was done using Accu check Performa glucometer. Rats with high blood glucose $(250 \mathrm{mg} / \mathrm{dl}$ or more $)$ were considered diabetic (Maduka et al., 2003).

Preparation of Rosemary and Basil leaves powder: Rosemary and Basil leaves were purchased from local medicinal plants farm. The plant materials were washed of residual soil and dried under-vacuum drying machine as follows: Temperature at $50^{\circ} \mathrm{C}$, under-vacuum of 0.3 bar and time for 3 hours, till complete drying and ground to fine powder. The fine powder of Rosemary and Basil Leaves were stored in air tight plastic containers until used (Labban et al., 2014).

At the end of the experimental period, rats were overnight fasted, blood samples were withdrawn. Serum was separated for determination of serum fasting glucose (Maughan, 1982), insulin (Urdal et al., 1992), (GSH) glutathione (Beutler et al., 1963), (CAT) catalase (Goth, 1991), (SOD) superoxide dismutase (Minami and Yoshikawa, 1979), (LDH) lactate dehydrogenase (Kjeld, 1972) and (MDA) malondialdehyde (Yoshioka et al., 1979). Samples were stored at - 20 oC until assayed.

Statistical analysis: Data input and analysis were done using SPSS computer program. All results were expressed as mean \pm standard error. Mean values of the different groups were compared using a one-way analysis of variance (ANOVA) or Kruskall Wallis test. Least significant difference (LSD) post hoc analysis was used to identify significantly different mean values. $P$ value $<0.05$ was accepted to denote a significant difference. 


\section{RESULTS}

- Changes in blood glucose and insulin levels in the tested groups (Table 1):

When compared to group I, results of the present work showed that induction of diabetes in group II led to significant increase in serum fasting blood glucose level from $97.8 \pm 4.3 \mathrm{mg} / \mathrm{dl}$ to $232.7 \pm 8.3$ $\mathrm{mg} / \mathrm{dl}$, and significant decrease in serum fasting insulin level from $2.79 \pm 0.4$ $\mathrm{uIU} / \mathrm{ml}$ to $1.02 \pm 0.1 \mathrm{uIU} / \mathrm{ml}$.

When compared to group II, Results of the present work showed that Rosemary diet fortification led to significant decrease in serum fasting blood glucose level from $232.7 \pm 8.3 \mathrm{mg} / \mathrm{dl}$ to $145.6 \pm$
$9.45 \mathrm{mg} / \mathrm{dl}$ and significant increase in serum fasting insulin level from $1.02 \pm 0.1$ $\mathrm{uIU} / \mathrm{ml}$ to $1.93 \pm 0.2 \mathrm{uIU} / \mathrm{ml}$. Basil diet fortification led to significant decrease in serum fasting blood glucose level from $232.7 \pm 8.3 \mathrm{mg} / \mathrm{dl}$ to $138.9 \pm 6.34 \mathrm{mg} / \mathrm{dl}$ and significant increase in serum fasting insulin level from $1.02 \pm 0.1 \mathrm{uIU} / \mathrm{ml}$ to $1.85 \pm 0.21 \mathrm{uIU} / \mathrm{ml}$. Combined Rosemary and Basil diet fortification led to significant decrease in serum fasting blood glucose level from $232.7 \pm 8.3$ $\mathrm{mg} / \mathrm{dl}$ to $121.3 \pm 5.23 \mathrm{mg} / \mathrm{dl}$ and significant increase in serum fasting insulin level from $1.02 \pm 0.1 \mathrm{uIU} / \mathrm{ml}$ to 2.1 $\pm 0.3 \mathrm{uIU} / \mathrm{ml}$.

Table (1): Changes in blood glucose and insulin levels in the tested groups

\begin{tabular}{|c|c|c|c|c|c|}
\hline & \multicolumn{5}{|c|}{ Mean \pm S.E } \\
\cline { 2 - 6 } & $\begin{array}{c}\text { Group I } \\
\text { (10 rats) }\end{array}$ & $\begin{array}{c}\text { Group II } \\
\text { (10 rats) }\end{array}$ & $\begin{array}{c}\text { Group III } \\
\text { (10 rats) }\end{array}$ & $\begin{array}{c}\text { Group IV } \\
\text { (10 rats) }\end{array}$ & $\begin{array}{c}\text { Group V } \\
\text { (10 rats) }\end{array}$ \\
\hline $\begin{array}{c}\text { Fasting blood } \\
\text { glucose (mg/dl) }\end{array}$ & $97.8 \pm 4.3$ & $232.7 \pm 8.3$ & $145.6 \pm 9.45$ & $138.9 \pm 6.34$ & $121.3 \pm 5.23$ \\
\cline { 3 - 6 } & $\mathrm{P}<0.05$ & $\mathrm{P}<0.05$ & $\mathrm{P}<0.05$ & $\mathrm{P}<0.05$ \\
\hline $\begin{array}{c}\text { Fasting insulin } \\
\text { (uIU/ml) }\end{array}$ & $2.79 \pm 0.4$ & $1.02 \pm 0.1$ & $1.93 \pm 0.2$ & $1.85 \pm 0.21$ & $2.1 \pm 0.3$ \\
\cline { 3 - 6 } & $\mathrm{P}<0.05$ & $\mathrm{P}<0.05$ & $\mathrm{P}<0.05$ & $\mathrm{P}<0.05$ \\
\hline
\end{tabular}

Group I: Control group.

Group II: Alloxan treated group.

Group III: Rosemary-treated group.

Group IV: Basil-treated group.

Group V: Combined Rosemary and Basil-treated group.

Group II was compared to group I.

Groups III, IV and V were compared to group II.

- Changes in the oxidant/antioxidant levels in the tested groups (Table 2):

When compared to group I, results of the present work showed that induction of diabetes in group II led to significant decrease in serum GSH level from $2.15 \pm$ $0.25 \mathrm{U} / \mathrm{ml}$ to $1.2 \pm 0.14 \mathrm{U} / \mathrm{ml}$, significant decrease in serum CAT level from $2.79 \pm$ $0.4 \mathrm{U} / \mathrm{ml}$ to $1.12 \pm 0.1 \mathrm{U} / \mathrm{ml}$, significant decrease in serum SOD level from $9.02 \pm$ $0.83 \mathrm{U} / \mathrm{ml}$ to $3.98 \pm 0.62 \mathrm{U} / \mathrm{ml}$, significant increase in serum LDH level from $39.44 \pm$ $1.37 \mathrm{U} / \mathrm{ml}$ to $57.94 \pm 2.69 \mathrm{U} / \mathrm{ml}$ and significant increase in serum MDA level from $13.76 \pm 0.26 \mathrm{nmol} / \mathrm{ml}$ to $23.24 \pm$ $2.14 \mathrm{nmol} / \mathrm{ml}$.

When compared to group II, results of the present work showed that Rosemary diet fortification led to significant increase in serum GSH level from $1.2 \pm 0.14 \mathrm{U} / \mathrm{ml}$ to $1.7 \pm 0.23 \mathrm{U} / \mathrm{ml}$, significant increase in serum CAT level from $1.12 \pm 0.1 \mathrm{U} / \mathrm{ml}$ to $1.93 \pm 0.2 \mathrm{U} / \mathrm{ml}$, significant increase in serum SOD level from $3.98 \pm 0.62 \mathrm{U} / \mathrm{ml}$ to $6.27 \pm 0.43 \mathrm{U} / \mathrm{ml}$, significant decrease in serum LDH level from $57.94 \pm 2.69$ 
$\mathrm{U} / \mathrm{ml}$ to $46.34 \pm 2.34 \mathrm{U} / \mathrm{ml}$ and significant decrease in serum MDA level from 23.24 $\pm 2.14 \mathrm{nmol} / \mathrm{ml}$ to $18.36 \pm 1.98 \mathrm{nmol} / \mathrm{ml}$. Basil diet fortification led to significant increase in serum GSH level from $1.2 \pm$ $0.14 \mathrm{U} / \mathrm{ml}$ to $1.78 \pm 0.31 \mathrm{U} / \mathrm{ml}$, significant increase in serum CAT level from $1.12 \pm 0.1 \mathrm{U} / \mathrm{ml}$ to $1.85 \pm 0.21 \mathrm{U} / \mathrm{ml}$, significant increase in serum SOD level from $3.98 \pm 0.62 \mathrm{U} / \mathrm{ml}$ to $5.89 \pm 0.46$ $\mathrm{U} / \mathrm{ml}$, significant decrease in serum $\mathrm{LDH}$ level from $57.94 \pm 2.69 \mathrm{U} / \mathrm{ml}$ to $48.21 \pm$ $1.82 \mathrm{U} / \mathrm{ml}$ and significant decrease in serum MDA level from $23.24 \pm 2.14$ $\mathrm{nmol} / \mathrm{ml}$ to $17.74 \pm 1.62 \mathrm{nmol} / \mathrm{ml}$.

Combined Rosemary and Basil diet fortification led to significant increase in serum GSH level from $1.2 \pm 0.14 \mathrm{U} / \mathrm{ml}$ to $1.99 \pm 0.27 \mathrm{U} / \mathrm{ml}$, significant increase in serum CAT level from $1.12 \pm 0.1 \mathrm{U} / \mathrm{ml}$ to $2.1 \pm 0.3 \mathrm{U} / \mathrm{ml}$, significant increase in serum SOD level from $3.98 \pm 0.62 \mathrm{U} / \mathrm{ml}$ to $7.21 \pm 0.22 \mathrm{U} / \mathrm{ml}$, significant decrease in serum $\mathrm{LDH}$ level from $57.94 \pm 2.69$ $\mathrm{U} / \mathrm{ml}$ to $41.12 \pm 1.23 \mathrm{U} / \mathrm{ml}$ and significant decrease in serum MDA level from 23.24 $\pm 2.14 \mathrm{nmol} / \mathrm{ml}$ to $15.57 \pm 0.83 \mathrm{nmol} / \mathrm{ml}$.

Table (2): Changes in the oxidant/antioxidant levels in the tested groups

\begin{tabular}{|c|c|c|c|c|c|}
\hline \multirow{2}{*}{ Groups } & \multicolumn{5}{|c|}{ Mean \pm S.E } \\
\hline & $\begin{array}{l}\text { Group I } \\
\text { (10 rats) }\end{array}$ & $\begin{array}{l}\text { Group II } \\
\text { (10 rats) }\end{array}$ & $\begin{array}{l}\text { Group III } \\
\text { (10 rats) }\end{array}$ & $\begin{array}{c}\text { Group IV } \\
\text { (10 rats) }\end{array}$ & $\begin{array}{c}\text { Group V } \\
\text { (10 rats) }\end{array}$ \\
\hline \multirow{2}{*}{ GSH (U/ml) } & \multirow{2}{*}{$2.15 \pm 0.25$} & $1.2 \pm 0.14$ & $1.7 \pm 0.23$ & $1.78 \pm 0.31$ & $1.99 \pm 0.27$ \\
\hline & & $P<0.05$ & $\mathrm{P}<0.05$ & $\mathrm{P}<0.05$ & $\mathrm{P}<0.05$ \\
\hline \multirow{2}{*}{ CAT (U/ml) } & \multirow{2}{*}{$2.79 \pm 0.4$} & $1.12 \pm 0.1$ & $1.93 \pm 0.2$ & $1.85 \pm 0.21$ & $2.1 \pm 0.3$ \\
\hline & & $\mathrm{P}<0.05$ & $\mathrm{P}<0.05$ & $\mathrm{P}<0.05$ & $P<0.05$ \\
\hline \multirow{2}{*}{ SOD $(\mathbf{U} / \mathbf{m l})$} & \multirow{2}{*}{$9.02 \pm 0.83$} & $3.98 \pm 0.62$ & $6.27 \pm 0.43$ & $5.89 \pm 0.46$ & $7.21 \pm 0.22$ \\
\hline & & $\mathrm{P}<0.05$ & $\mathrm{P}<0.05$ & $\mathrm{P}<0.05$ & $\mathrm{P}<0.05$ \\
\hline \multirow{2}{*}{ LDH (U/ml) } & \multirow{2}{*}{$39.44 \pm 1.37$} & $57.94 \pm 2.69$ & $46.34 \pm 2.34$ & $48.21 \pm 1.82$ & $41.12 \pm 1.23$ \\
\hline & & $\mathrm{P}<0.05$ & $\mathrm{P}<0.05$ & $\mathrm{P}<0.05$ & $\mathrm{P}<0.05$ \\
\hline \multirow{2}{*}{$\begin{array}{c}\text { MDA } \\
(\mathbf{n m o l} / \mathrm{ml})\end{array}$} & \multirow{2}{*}{$13.76 \pm 0.26$} & $23.24 \pm 2.14$ & $18.36 \pm 1.98$ & $17.74 \pm 1.62$ & $15.57 \pm 0.83$ \\
\hline & & $\mathrm{P}<0.05$ & $\mathrm{P}<0.05$ & $\mathrm{P}<0.05$ & $\mathrm{P}<0.05$ \\
\hline
\end{tabular}

Group I: Control group.

Group II: Alloxan treated group.

Group III: Rosemary-treated group.

Group IV: Basil-treated group.

Group V: Combined Rosemary and Basil-treated group.

Group II was compared to group I.

Groups III, IV and V were compared to group II.

\section{DISCUSSION}

The present work was designed to evaluate the possible protective effects of Rosmarinus officinalis and/or Ocimum basilicum on induced diabetes in adult male albino rats.

In the present study, induction of diabetes led to disturbed pancreatic $\beta$ cell function indicated by significant elevation of blood glucose level associated with significant decrease in insulin levels in addition to disturbed oxidant-antioxidant status evidenced by elevated serum MDA and LDH levels combined with reduced GSH, CAT and SOD levels. These results agreed with Al-Shawabkeh and Jamal (2019) who stated that alloxan induces diabetes through destruction of pancreatic $\beta$ cell leading to decreased insulin secretion and defective glucose utilization by the tissue and related that to decreased 
muscle mass due to reduced its proteins content as a result of diabetes. Also, Saed et al. (2019) has reported that alloxan targets the pancreatic $\beta$ cell causes its destruction which make cells less active and lead to poor glucose utilization by tissues and appearance of diabetes.

In alloxan induced diabetes, disturbed oxidant /antioxidant was reported by Akomas et al. (2014) who reported that free radicals are formed disproportionately in diabetes by glucose auto-oxidation, thus resulting in consumption of antioxidant defenses (catalase level) which lead to disruption of cellular function and oxidative damage to pancreatic $\beta$ cells which are particularly sensitive to damage by free radicals because of their low level of free radical scavenging enzymes that leads to hyperglycemic condition.

In the present work, diet fortification by Rosmarinus officinalis and/or Ocimum Basilicum led to improved diabetic status associated with enhanced oxidant /antioxidant system activity indicated by decreased glucose, LDH and MDA levels in association with increased insulin, GSH, Cat and SOD levels.

The hypoglycemic effects of Rosemary and/or Basil might be related to their positive impact on pancreatic $\beta$-cells function, either through direct or indirect actions. The direct actions might be triggered through a stimulatory effect of the Rosemary and Basil on insulin secretion. Indeed, elevation of serum insulin levels stimulates glucose utilization by the peripheral tissues and glucose uptake by the cells, consequently leading to a reduction in serum glucose levels (Emam, 2012). El-Beshbishy and Bahashwan (2012) has reported that Basil and Rosemary might potentiate insulin secretion indirectly through their antioxidant properties. They contain polyphenolic compounds and flavonoids which act as free radical scavengers. In turn, these compounds prevent tissue degeneration and, consequently, prevent progressive $\beta$-cell impairment; hence, glycemic status is improved. Also, Hannan et al. (2014) has reported that the decreased glucose levels due to dietary supplementation with Basil and/or Rosemary leaves could be attributed to inhibition of carbohydrate metabolic pathway through inhibition of amylase enzyme activity. Hence, inhibition of carbohydrates breakdown results in impeded glucose release and, consequently, a reduction in serum glucose levels. It has reported that Basil plant is known for its medicinal properties. Its leaves showed significant reduction in blood sugar level in both normal and alloxan induced diabetic rats (Oraon et al., 2017).

Rosmarinic acid, components of the herb Rosemary, reportedly exerts favorable metabolic actions. It induces significant phosphorylation of AMPdependent kinase and its downstream acetyl-CoA carboxylase 1 in the liver cells, Glucose-6-phosphatase and phosphoenolpyruvate carboxykinase 1, rate-limiting enzymes of hepatic gluconeogenesis possibly as a result of AMPK activation exert a protective effect against diabetes and fatty liver disease (Hasei et al., 2021).

Results of the present work were in agreement with Labban et al. (2014) who reported that Rosemary significantly decreases malondialdehyde (MDA) 
contents and acts as a cytoprotective agent reflecting a free radical-scavenging activity that elicited widespread damage to cell constituents such as membrane lipids and significantly increased the normal cells viability and the antioxidant enzymes activity as catalase enzyme. $\mathrm{El}$ Kader et al. (2012) has reported that Rosemary administration reduced MDA levels significantly in respect to diabetic non-treated group. Such decrease in the MDA level by Rosemary leaves extract may be attributed to the antioxidant properties that inhibited lipid peroxidation. This in turn stabilizes the reactive radicals preserving the cellular functions. Wang et al. (2017) also reported that feeding with Rosemary significantly increases the enzyme activity of superoxide dismutase (SOD) and catalase (CAT), and significantly decreases the level of malondialdehyde.

It has been reported that the hypoglycemic activity of Rosemary could be attributed to increased total antioxidant capacity leading to inhibition of tissue damage and potentiation of pancreatic $\beta$ cell secretion (Emam, 2012).

It has also reported that inhibition of cortisol activity and the antioxidant potency of the polyphenolic compounds in Rosemary and Basil prevented the progressive impairment of pancreatic $\beta$ cell function. In addition, the ability of Basil to reduce the rates of carbohydrate metabolism and glucose release through amylase inhibitory activity has also postulated as a mechanism of reduction of blood glucose (Hannan et al., 2014 and Ezeani et al., 2017).

In the present work, it was noted that either Basil or Rosemary diet fortification lead to improved glycemic control and antioxidant property however, combination of both leaves powder resulted in more enhancement of their anti-diabetic and antioxidant activity then each one alone. These was in agreement with Ahmed et al. (2020) who reported that combination of herbals achieves better glycemic control in a short period with a small dose than single herb which helps avoidance of side effects of large dose of each one alone.

\section{CONCLUSION}

Diet fortification with Rosemary and Basil leaves separately or in combination mediated promising antidiabetic effects through scavenging of harmful free radicals and enhanced pancreatic $\beta$ cell functions exerting a hypoglycemic effect and improved the oxidant/antioxidant capacity in alloxan induced diabetes in rats. Consequently, addition of these herbs to human food could be of value on modulation of blood glucose levels in addition to their positive impact on antioxidant status.

\section{REFERENCES}

1. Ahmed, A., Khan, A., Batool, Z, Hassan, M. and Khaliq, S. (2020): Medicinal effects of saffron and chamomile on diabetes mellitus and associated hyperlipidemia and memory impairment. Pak. J. Pharm. Sci., 33 (3): $1191-1198$.

2. Akomas, S.C., Okafor, .A. I. and Ijoima, S. N. (2014): Glucose level, hematological parameters and lipid profile in ficus sur treated diabetic rats. Comprehensive Journal of Agricultural and Biological Science, 2(1): 5 -11.

3. Al-Nahdi, H. S. (2012): Effect of Rosmarinus officinalis extract on some 


\section{SAIED SHARAF MOHAMED}

cardiac enzymes of streptozotocininduced diabetic rats. J. Health Sci., 2 (2): $33-37$.

4. Al-Shawabkeh, M. and Jamal, A. (2019): Effect of cinnamon administration on fertility of normal and diabetic male rats. Pak. J. Nut., 18 (5): 470 - 475.

5. Asano, R., Sales, M., Browne, R. and Morase, R. (2014): Acute effects of physical exercise in type 2 diabetes: a review. World Journal Diabetes, 5 (5): $659-665$.

6. Beutler, E., Duron, O. and Kelly, B. (1963): Improved method for the determination of blood glutathione. J. Lab, Clin. Med., 61: 882 - 888.

7. El-Beshbishy, H. A. and Bahashwan, S. A. (2012): Hypoglycemic effect of Basil (Ocimum Basilicum) aqueous extract is mediated through inhibition of $\alpha$ glucosidase and $\alpha$-amylase activities: An in vitro study. Toxicol. Ind. Health, 28 (1): 42 - 50.

8. El-Kader, M.A.A., El-Sammad, N.M. and Hamdy, T. (2012): The Protective Role of Rosemary (Rosmarinus officinalis) in Lead Acetate Induced Toxicity in Rats. Journal of Applied Sciences Research, 8: 3071 - 3082.

9. Emam, M. A. (2012): Comparative evaluation of antidiabetic activity of Rosmarinus officinalis L. and Chamomile recutita in streptozotocin-induced diabetic rats. Agric. Biol. J. North Am., 3 (6): 247 -252 .

10. Ezeani, C., Ezenyi, I., Okoye, T. and Okoli, C. (2017): Ocimum Basilicum extract exhibits antidiabetic effects via inhibition of hepatic glucose mobilization and carbohydrate metabolizing enzymes. J. Intercult. Ethnopharmacol., 6 (1): 22 28.

11. Goth, L. (1991): A simple method for determination of serum catalase activity and revision of reference range. Clinica. Chimica. Acta., 196 (2-3): 143 - 151.

12. Hannan, J. M. A., Ojo, O. O., Ali, L., Rokeya, B., Khaleque, J., Akhter, M., Flatt, P. R. and Abdel-Wahab, Y. H. A. (2014): Actions underlying antidiabetic effects of Ocimum sanctum leaf extracts in animal models of Type 1 and Type 2 diabetes. Eur. J. Med. Plants, 5 (1): 1 - 12.

13. Hasei, S., Yamamotoya, T., Nakatsu, Y., Ohata, Y., Itoga, S., Nonaka, Y., Matsunaga, Y., Sakoda, H., Fujishiro, M., Kushiyama, A. and Asano, T. (2021): Carnosic Acid and Carnosol Activate AMPK, Suppress Expressions of Gluconeogenic and Lipogenic Genes, and Inhibit Proliferation of HepG2 Cells. Int. J. Mol. Sci., 22 (8): 4040 - 4048.

14. Hassanpour, G., Hosseini, S., Keikhosravi, F. and Mohamed, $M$. (2017): The effect of swimming training with cinnamon extract on hematological factors in diabetic rats. Iranian J. of Diabetes and Obesity, 9(3): 101 - 106.

15. Hosni, A., Moneim, A., Abdel-Reheim, E. and Mohamed, M. (2017): Cinamaldehyde potentially attenuates gestational hyperglycemia in rats through modulation of PPAR gamma, proinflammatory cytokines and oxidative stress. Biomed Pharmacotherapy, 88: 52 60.

16. Kjeld, M. (1972): An automated colorimetric method for the estimation of Lactate lactate dehydrogenase activity in serum. Scand. J. Clin. Lab. Invest., 29 (4): $421-425$.

17. Labban, L., Mustafa, U. E. and Ibrahim, Y. M. (2014): The effects of Rosemary (Rosmarinus officinalis) leave powder on glucose level lipid profile and lipid peroxidation. Int. J. Clin. Med., 5 (6): 297 - 304. 
18. Maduka, H., Obi, F and Mamaza, Y. (2003): Effect of chloroqune on blood glucose and cholesterol levels in alloxan induced diabetic rabbits. J. of Biological Sciences, 3 (10): 875 - 881.

19. Maughan, R. J. (1982): A simple, rapid method for the determination of glucose, lactate, pyruvate, alanine, 3hydroxybutyrate and acetoacetate on a single 20-mul blood sample. Clin. Chim. Acta, 122: 231 - 240.

20. Minami, M. and Yoshikawa, H. (1979): A simplified assay method of superoxide dismutase activity for clinical use. Clin. Chem. Acta, 92: 337 - 342.

21. Oraon, L., Atanu, J., Prajapati, P. S. and Suvera, P. (2017): Application of herbs in functional dairy products - a review. J. Dairy Vet. Anim. Res., 5 (3): $109-115$.

22. Ranasinghe, P., Jayawardina, R., Premakumara, G. and Katulanda, P. (2017): evaluation of pharmacodynamics and safety of cinnamomum zeylanicum (Ceylon cinnamon) in health adults: study protocol for phase I clinical trial. M. O. J. bioequivalence Bioavailability, 3 (2): 28 35.

23. Saed, L., Deihim, Z., Nagahshabandi, M., Rajabnia, M. and Naleini, S. (2019): Cardiovascular events in patients 10 years history of type 2 diabetes mellitus. Diabetes Metab. Syndr., 13: 68 72.
24. Suanarunsawat, T., Ayutthaya, W. D. N., Thirawarapan, S. and Poungshompoo, S. (2014): Antioxidative, anti-hyperglycemic and lipidlowering effects of aqueous extracts of Ocimum sanctum L. leaves in diabetic rats. Food Nutr. Sci., 5 (9): 801 - 811.

25. Urdal, P., Broch, S. and Landaas, S. (1992): Rapid immunometric measurement of $\mathrm{C}$ - reactive protein in whole blood. Clinical Chemistry J., 142: 580 - 584 .

26. Wang, H. L., Sun, Z. O., Rehman, R. U., Wang, H., Wang, Y. F. and Wang, H. (2017): Rosemary extract-mediated lifespan extension and attenuated oxidative damage in drosophila melanogaster fed on high-fat diet. J. Food Sci., 82 (4): 1006 -1011.

27. Yoshioka, T., Kawada, K., Shimada, T. and Mori, M. (1979): Lipid peroxidation in maternal and cord blood and protective mechanism against activated oxygen toxicity in the blood. Am. J. Obestet. Gynecol., 135: 372 - 376. 
تأثثير استخدام الروزمارى و /أو الريحان على مرض السكرى المحدث فى ذكور الجرذان البيض البـاء البالغة

\section{سعيد شرف محمد الجران}

\section{قسم الفسيولوجيا الطبية، كلية الطب، جامعة الأزهر، القاهرة}

E-mail: saidmontaser859@gmail.com

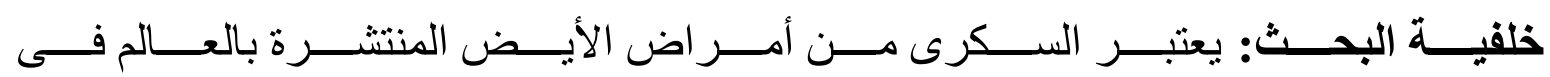

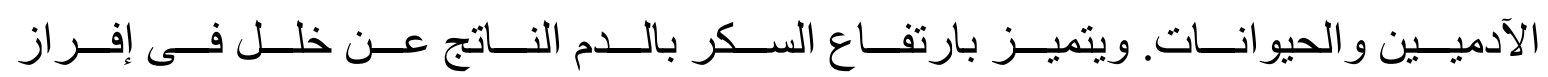
الإنسولين من خلايا بيتا بالبنكرياس أو مقاومة الإنسولين أو الاثثين معا.

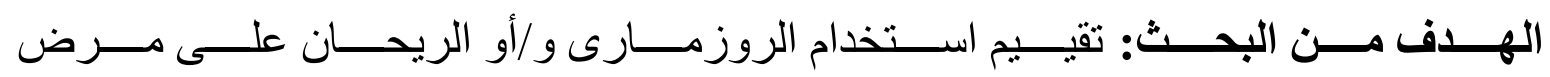
السكرى المحدث فى ذكور الجرذان البيضاء البالغة.

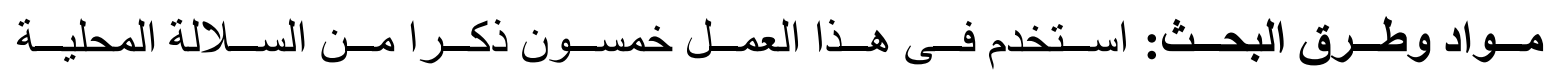

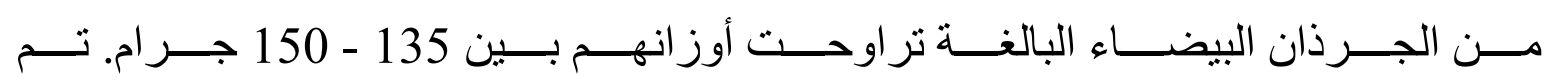

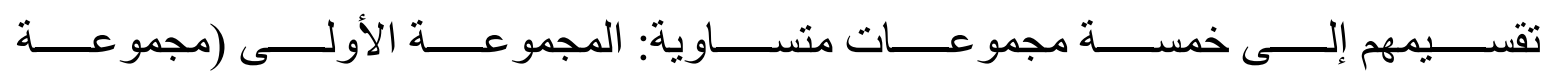

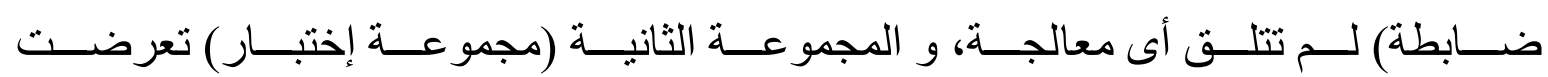

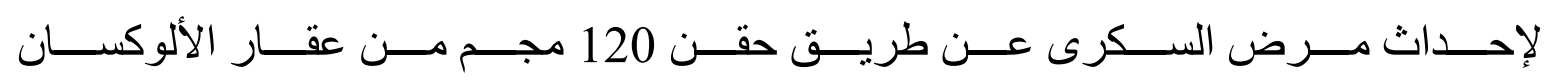

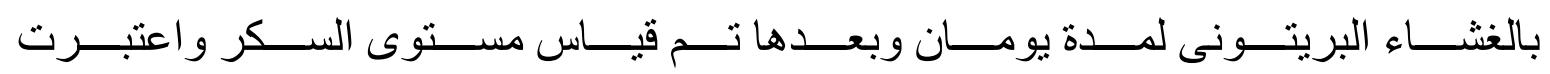

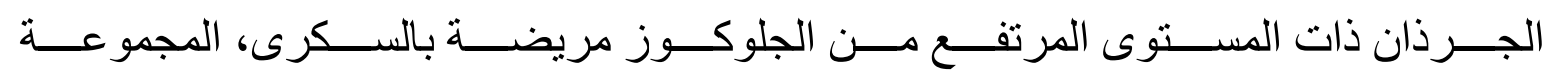

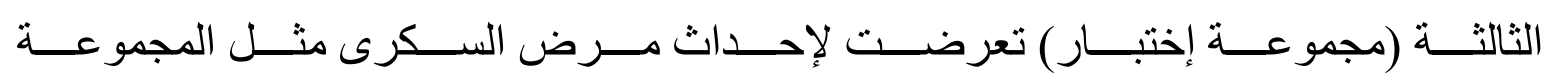

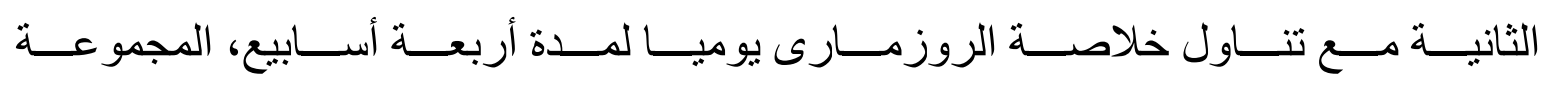

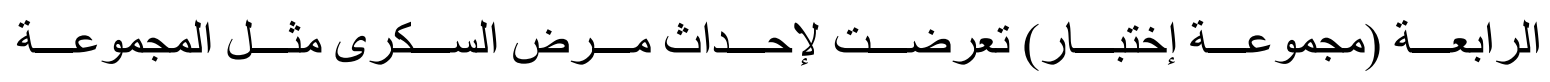

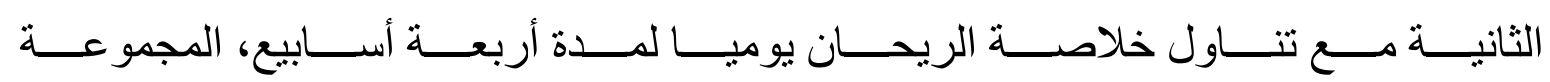

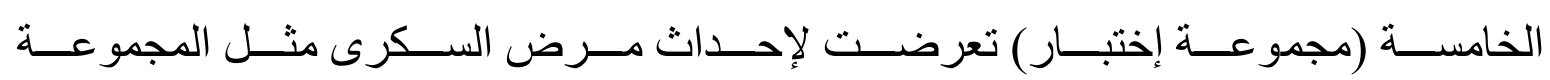

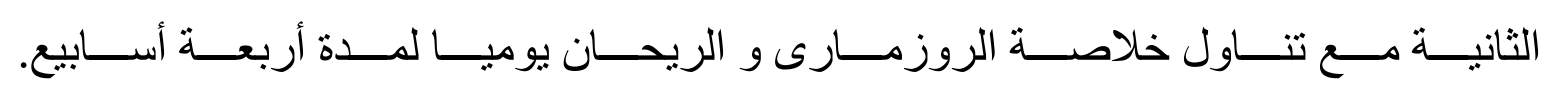

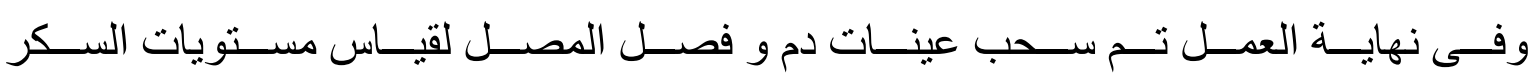
و الإنسولين، بالإضافة إلى بعض عو امل ومضادات التأكسد. 


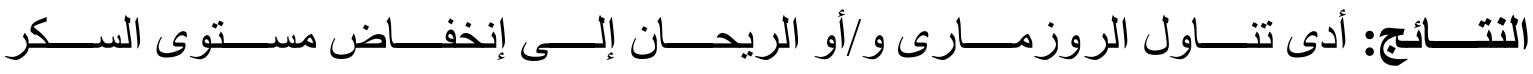

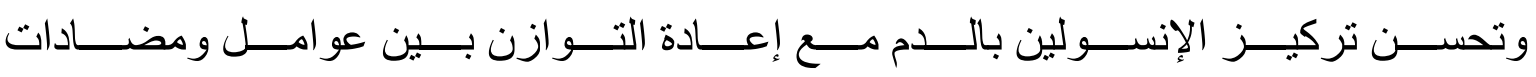

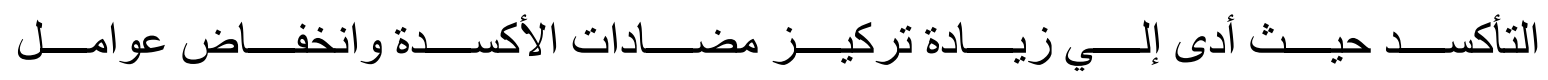
التأكسد بدلالات إحصائية في جرذان هذا العمل.

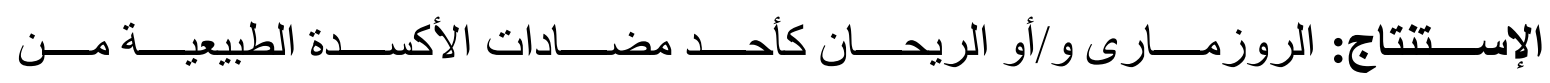

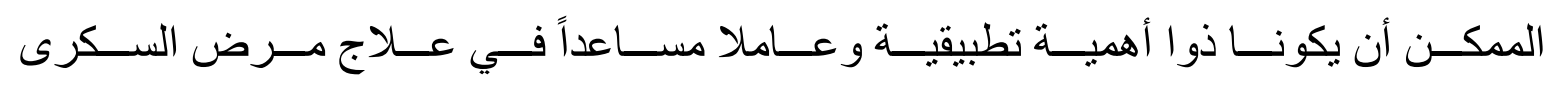

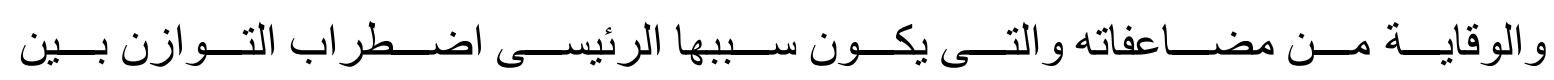
عو امل ومضادات التأكسد بالجسم.

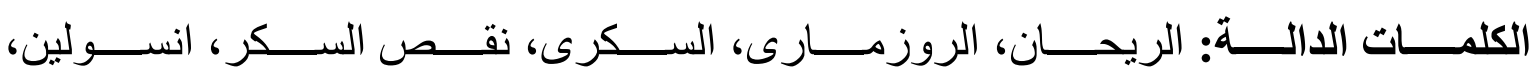
مضادات التأكسد. 